\title{
Nodal involvement adversely affects prognosis in pulmonary carcinoid tumors
}

\author{
Pulmoner karsinoid tümörlerde nodal tutulum prognozu kötü etkiler
}

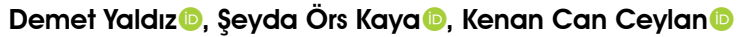

Department of Thoracic Surgery, Dr. Suat Seren Chest Diseases and Surgery Training and Research Hospital, izmir, Turkey

\begin{abstract}
Background: This study aims to analyze the prognostic factors affecting survival in pulmonary carcinoid tumors.

Methods: Gender, age, smoking habit, comorbidity, localization of the tumor, T status, $\mathrm{N}$ status, histological type, and pathological stage of patients who had undergone resection of pulmonary carcinoid tumor between January 1, 2005 and December 31, 2016 were retrospectively reviewed.

Results: A total of 47 patients (18 male, 29 female; mean age 50.5 years; range, 23 to 74 years) consisting of 40 typical and 7 atypical carcinoid tumor cases were included in our study. Anatomical resection and systematic mediastinal lymph node dissection was performed on all patients. Pathological studies revealed lymphatic involvement in six patients $\left(12.8 \% ; 4 \mathrm{pN}_{1}\right.$ and $\left.2 \mathrm{pN}_{2}\right)$. In the typical group $(\mathrm{n}=40)$, three patients were classified $\mathrm{N}_{1}(7.5 \%)$ and one patient $\mathrm{N}_{2}(2.5 \%)$. In the atypical group $(\mathrm{n}=7)$, one patient were classified $\mathrm{N}_{1}(14.3 \%)$ and one patient $\mathrm{N}_{2}(14.3 \%)$. Throughout the study, four patients with typical histology $(10 \%)$ and two patients with atypical histology (28.6\%) had nodal involvement. All six patients with nodal involvement underwent adjuvant radiotherapy. Atypical histology $(p=0.005)$ and nodal involvement $(p=0.008)$ were determined as negative prognostic factors in statistical analysis.
\end{abstract}

Conclusion: Systematic hilar and mediastinal nodal dissection play a crucial role in the surgical treatment of pulmonary carcinoid tumors.

Keywords: Nodal involvement; prognostic factors; pulmonary carcinoid tumor.

Primary bronchopulmonary carcinoid tumors constitute approximately 1 to $2 \%$ of all pulmonary tumors. ${ }^{[1]}$ All bronchopulmonary carcinoids are classified as malignant, despite their slow growth, they can invade and metastasize. They can be

\section{$\ddot{O} Z$}

Amaç: Bu çalışmada pulmoner karsinoid tümörlerde sağkalımı etkileyen prognostik faktörler incelendi.

Çalışma planı: 1 Ocak 2005 - 31 Aralık 2016 tarihleri arasında, pulmoner karsinoid tümör dolayisiyla rezeksiyon uygulanan olgularda cinsiyet, yaş, sigara kullanımı, eşlik eden hastalık, tümörün yerleşim yeri, $\mathrm{T}$ durumu, $\mathrm{N}$ durumu, histolojik tip ve patolojik evre geriye dönük olarak gözden geçirildi.

Bulgular: Çalışmamıza 40 tipik ve 7 atipik karsinoid tümör olmak üzere 47 hasta (18 erkek, 29 kadın; ort yaş 50.5 yıl; dağılım, 23-74 yıl) dahil edildi. Tüm hastalara anatomik rezeksiyon ve sistematik mediastinal lenf nodül diseksiyonu uyguland. Patolojik değerlendirmede altı hastada lenfatik tutulum saptand $\left(\% 12.8 ; 4 \mathrm{pN}_{1}\right.$ ve $\left.2 \mathrm{pN}_{2}\right)$. Tipik grupta $(\mathrm{n}=40)$ üç hasta $\mathrm{N}_{1}(\% 7.5)$ ve bir hasta $\mathrm{N}_{2}(\% 2.5)$ olarak sınıflandırıldı. Atipik grupta $(\mathrm{n}=7)$ bir hasta $\mathrm{N}_{1}(14.3 \%)$ ve bir hasta $\mathrm{N}_{2}(14.3 \%)$ olarak sınıflandırıldı. Çalışma boyunca, tipik histolojisi olan dört (\%10) ve atipik histolojisi olan iki (\%28.6) hastada nodal tutulum vardı. Nodal tutulum olan altı hastanın tamamına adjuvan tedavi uygulandi. Atipik histoloji $(\mathrm{p}=0.005)$ ve nodal tutulum $(\mathrm{p}=0.008)$ istatistik çalışmada kötü prognostik faktör olarak saptandi.

Sonuç: Pulmoner karsinoid tümörün cerrahi tedavisinde, sistematik hiler ve mediastinal lenf nodu diseksiyonunun önemli rolü vardır.

Anahtar sözcükler: Nodal tutulum; prognostik faktörler; pulmoner karsinoid tümör.

histopathologically classified as typical or atypical. Although surgical resection is the standard treatment for pulmonary carcinoid tumors, controversy exists regarding factors that affect survival. Many experiences of surgical management of pulmonary

Received: November 17, 2017 Accepted: April 04, 2018

Correspondence: Demet Yaldız, MD. Dr. Suat Seren Göğüs Hastalıkları ve Cerrahisi Eğitim ve Araștırma Hastanesi, Göğüs Cerrahisi Kliniği, 35170 Konak, İzmir, Turkey. Tel: +90 232 - 4333333 e-mail: demetyaldiz@gmail.com 
carcinoids have been reported, but there is no clear agreement on its main prognostic factors such as gender, age, smoking status, comorbidity, central versus peripheral localization, $\mathrm{T}$ status, histological type, $\mathrm{N}$ status, and pathological state.

\section{PATIENTS AND METHODS}

The study protocol was approved by the Dr. Suat Seren Chest Diseases and Thoracic Surgery Training and Research Hospital Ethics Committee. A written informed consent was obtained from each patient. The study was conducted in accordance with the principles of the Declaration of Helsinki. Patients who underwent anatomic lung resection for typical or atypical carcinoid tumor between January 2005 and December 2016 were retrospectively reviewed. Based on the 2004 World Health organization (WHO) classification, typical carcinoid tumors are defined as $<2$ mitoses per 10 high power fields, lacking necrosis, and larger than $5 \mathrm{~mm} .^{[2]}$ A total of 47 patients diagnosed with pulmonary carcinoid tumor consisted of $21(44.7 \%)$ male and $26(55.3 \%)$ female patients with ages ranging from 23-74 years. Evaluation of the patients included physical examination with pulmonary function tests, standard chest radiograph, total body computed tomography scans, and bronchoscopy. Thirteen patients (27.7\%) were asymptomatic at presentation. The most common presentation was evidence of bronchial obstruction $(\mathrm{n}=19 ; 40.4 \%)$, and 15 patients $(32.9 \%)$ presented with hemoptysis. None of our patients had evidence of carcinoid syndrome. In total, 17 patients (36.2\%) had additional comorbidities (diabetes mellitus, hypertension, coronary artery disease, chronic obstructive pulmonary disease, etc.). None of the patients in the study, had evidence of additional malignancy. Tumors visualized at bronchoscopy were classified as central $(n=37 ; 79 \%)$ or peripheral $(n=10$; 21.3\%). Tumors were located in the right lung (59.6\%) in 28 patients (central 21; 75.0\% and peripheral 7; $25.0 \%$ ), and in the left lung (40.4\%) in 19 patients (central 16; 84.2\% and peripheral $3 ; 15.8 \%$ ). Diagnosis was made by means of bronchoscopy in 21 patients (44.7\%) and by transthoracic needle aspiration biopsy in eight (17\%). Diagnosis was made with thoracotomy in 18 patients $(38.3 \%)$. No evidence of hilar and mediastinal lymphadenomegaly was identified in any patient preoperatively. Because no enlarged mediastinal lymph nodes were found in radiological evaluation, preoperative cervical mediastinoscopy was not performed in any of the patients. All patients

Table 1. Variables regarding tumor histology

\begin{tabular}{|c|c|c|c|c|c|}
\hline \multirow[b]{2}{*}{ Variables } & \multirow{2}{*}{$\begin{array}{c}\text { Total } \\
\mathrm{n} \\
\end{array}$} & \multicolumn{2}{|c|}{ Typical } & \multicolumn{2}{|c|}{ Atypical } \\
\hline & & $\mathrm{n}$ & $\%$ & $\mathrm{n}$ & $\%$ \\
\hline \multicolumn{6}{|c|}{ Localization of tumor } \\
\hline Central & 37 & 32 & 86.5 & 5 & 13.5 \\
\hline Peripheral & 10 & 8 & 80.0 & 2 & 20.0 \\
\hline \multicolumn{6}{|l|}{ Age (year) } \\
\hline$<50$ & 17 & 16 & 94.1 & 1 & 5.9 \\
\hline$>50$ & 30 & 24 & 80.0 & 6 & 20.0 \\
\hline \multicolumn{6}{|l|}{ Gender } \\
\hline Male & 18 & 14 & 77.8 & 4 & 22.2 \\
\hline Female & 29 & 26 & 89.7 & 3 & 10.3 \\
\hline \multicolumn{6}{|c|}{ Smoking habit } \\
\hline Yes & 17 & 13 & 76.5 & 4 & 23.5 \\
\hline No & 30 & 27 & 90.0 & 3 & 10.0 \\
\hline \multicolumn{6}{|l|}{$\mathrm{N}$ status } \\
\hline $\mathrm{N}_{0}$ & 41 & 37 & 90.2 & 4 & 9.8 \\
\hline $\mathrm{N}+$ & 6 & 4 & 66.6 & 2 & 33.4 \\
\hline \multicolumn{6}{|l|}{ Stage } \\
\hline IA & 25 & 22 & 88.0 & 3 & 12.0 \\
\hline IB & 14 & 12 & 85.7 & 2 & 14.3 \\
\hline IIA & 1 & 1 & 100 & - & - \\
\hline IIB & 5 & 4 & 80.0 & 1 & 20.0 \\
\hline IIIA & 2 & 1 & 50.0 & 1 & 50.0 \\
\hline
\end{tabular}


Table 2. Type of resection

\begin{tabular}{lccc}
\hline Surgical procedure & $\mathrm{n}$ & Total (n) & $\%$ \\
\hline Lobectomy & & & \\
$\quad$ Standard & 31 & 38 & 80.9 \\
$\quad$ Sleeve & 7 & & \\
Bilobectomy & & & \\
$\quad$ Standard & 6 & 7 & 14.9 \\
$\quad$ Sleeve & 1 & & \\
Pneumonectomy & & & \\
$\quad$ Standard & 1 & 2 & 4.3 \\
$\quad$ Sleeve & 1 & & \\
\hline
\end{tabular}

except eleven who were resected with video-assisted thoracoscopic surgery, underwent resection with serratus anterior sparing thoracotomy. Anatomic resection consisted of lobectomy, bilobectomy, pneumonectomy, or sleeve resection. At the start of the study, all patients underwent systematic hilar and mediastinal lymph node dissection with hypothetical preference and clinical decision. Bronchial margins frozen section was performed after bronchoplastic procedures in all cases. The seventh edition of the International Classification of TNM was used for staging. Operative mortality included patients who died within the first 30 days of the operation. Distributions of gender, age, smoking status, comorbidity, central versus peripheral localization, $\mathrm{T}$ status, histological

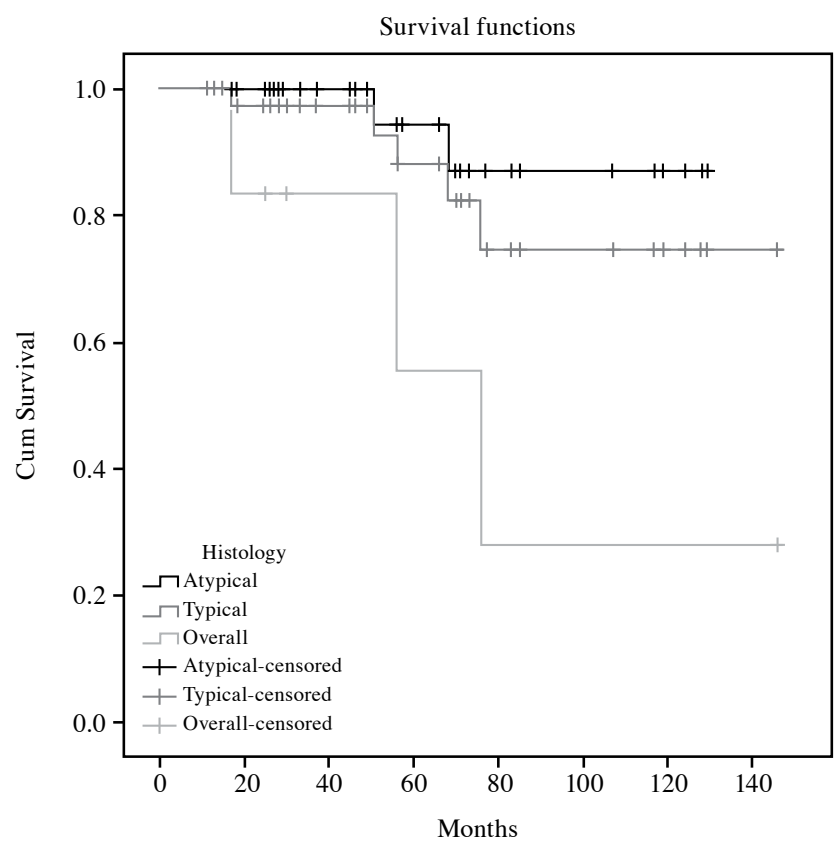

Figure 1. Prognostic influence of tumor histology. Univariable analysis (Kaplan-Meier) $(\mathrm{p}=0.005)$. type, $\mathrm{N}$ status, and pathological state were tested with the log-rank test. Cumulative survival probabilities were estimated with the Kaplan and Meier method.

\section{RESULTS}

According to histological findings, 40 patients (17 males, 23 females; mean age 50.5 years; range, 23 to 74 years) had typical carcinoid tumors, and seven patients (4 males, 3 females; mean age ?? years; range, 32 to 70 years) had atypical carcinoid tumors. Variations in terms of tumor histology are shown in Table 1 . Thirteen (33\%) of the 40 patients with typical tumors and four (57\%) of the seven patients with atypical tumors were smokers (overall $\mathrm{n}=17 ; 36.2 \%$ ).

Operations included lobectomy in 38 (80.9\%; sleeve lobectomy in 7), bilobectomy in seven (14.9\%; sleeve bilobectomy in 1), and pneumonectomy in two patients (4.3\%; sleeve tracheal pneumonectomy in 1) (Table 2). Non-anatomic resection was not performed in any of the patients. Eleven patients (23.4\%) underwent resection using a minimally invasive video-assisted recent approach. All patients underwent complete tumor resection. Systematic lymph node dissection was performed as a standard approach in all patients. The mean number of resected lymph nodes was 13 (range, 6-18) per patient.

The majority of the patients $(n=39)$ were in stage I (IA: 25, IB:14). Six were in stage II (IIA: 1, IIB:5), and

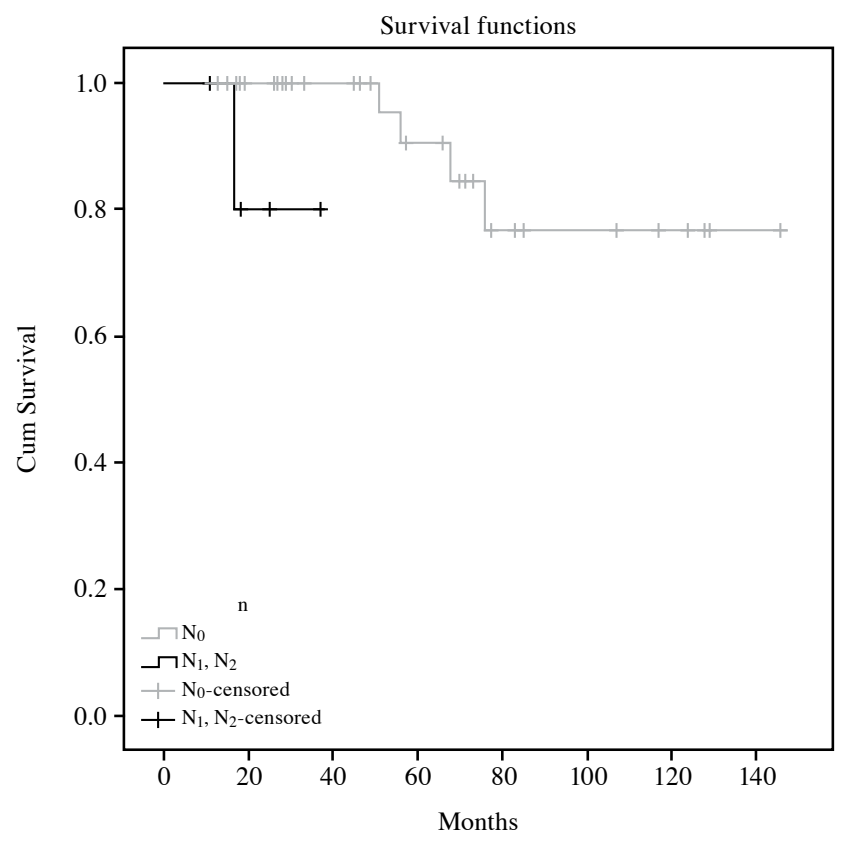

Figure 2. Prognostic influence of nodal invasion. Univariable analysis (Kaplan-Meier) $(\mathrm{p}=0.008)$. 
two were in stage IIIA. Lymph node metastasis was detected in six cases $\left(4 \mathrm{~N}_{1}, 2 \mathrm{~N}_{2}\right)$. Since radiotherapy may provide potential benefit, particularly in patients with lymph node-positive disease, the six patients with nodal involvement received adjuvant radiotherapy.

Postoperative mortality did not occur. Surgical complications included prolonged air leak $(n=1)$, postoperative hemorrhage $(n=1)$, and the morbidity rate was $4.3 \%$. Pathological studies demonstrated lymphatic spread in six patients $\left(12.8 \%\right.$; four $\mathrm{pN}_{1}$ and two $\left.\mathrm{pN}_{2}\right)$. In the typical group $(\mathrm{n}=40)$, three patients were classified $\mathrm{N}_{1}(7.5 \%)$ and one $\mathrm{N}_{2}(2.5 \%)$. In the atypical group $(n=7)$, one patient were classified $\mathrm{N}_{1}$ (14.3\%) and one $\mathrm{N}_{2}(14.3 \%)$. Overall, four patients with typical histology $(10 \%)$ and two patients with atypical histology (28.6\%) had nodal involvement. A total of 41 patients were free of nodal involvement (87.2\%). All patients $(n=47)$ were followed up for a total of 2,444 months with a median observation time of 52 months (mean, 38 months; range, 11 to 146 months). Follow-up ended on October 2017. Five patients died (three from cancer and two from unrelated causes). All three of the patients who died from cancer were atypical carcinoid. The overall five-year survival rate was $88.2 \%$ and the mean survival time was 124.4 months $(95 \%$ confidence interval, 107.4 to 141.3). Five-year survival was $94.4 \%$ in typical tumors $(\mathrm{n}=40)$, and $55.6 \%$ in atypical tumors $(\mathrm{n}=7 ; \mathrm{p}=0.005)$ (Figure 1). According to N0 status $(\mathrm{n}=41)$, five-year survival was $90.5 \%$, and $\mathrm{N}+$ status $(\mathrm{n}=6), 80.0 \%(\mathrm{p}=0.008)$ (Figure 2). Atypical histology and nodal invasion were found to be significant prognostic factors (Table 3). Tumor location (central versus peripheric), and stage did not seem to statistically affect survival (Figure 3 and 4). Five-year survival was $73.5 \%$ in male $(n=21)$ and $91.6 \%$ in female patients

Table 3. Univariate analysis of prognostic factors for survival

\begin{tabular}{|c|c|c|c|c|c|c|c|c|c|}
\hline & \multicolumn{2}{|c|}{ Total } & \multicolumn{2}{|c|}{ Dead } & \multicolumn{2}{|c|}{ Alive } & \multirow{2}{*}{$\begin{array}{c}\text { Estimated } \\
\text { survival } \\
\text { Mean } \pm \text { SE }\end{array}$} & \multirow{2}{*}{$\begin{array}{c}\begin{array}{c}\text { Estimated } \\
\text { proportion surviving }\end{array} \\
5 / 10 \text { year }\end{array}$} & \multirow[b]{2}{*}{$p$} \\
\hline & $\mathrm{n}$ & $\%$ & $\mathrm{n}$ & $\%$ & $\mathrm{n}$ & $\%$ & & & \\
\hline Gender & & & & & & & & & 0.433 \\
\hline Male & 21 & 44.7 & 3 & 14.3 & 18 & 85.7 & $119.4 \pm 13.5$ & $73.5 / 73.5$ & \\
\hline Female & 26 & 55.3 & 2 & 7.7 & 24 & 92.3 & $114.4 \pm 9.0$ & $100 / 74.1$ & \\
\hline Age & & & & & & & & & 0.474 \\
\hline$<50$ & 18 & 38.3 & 1 & 5.6 & 17 & 94.4 & $116.0 \pm 10.7$ & $100 / 80.0$ & \\
\hline$\geq 50$ & 29 & 61.7 & 4 & 13.8 & 25 & 86.2 & $120.1 \pm 11.3$ & $81.2 / 71.1$ & \\
\hline Smoking habit & & & & & & & & & 0.726 \\
\hline Yes & 17 & 36.2 & 1 & 5.9 & 16 & 94.1 & $137.4 \pm 8.3$ & $93.3 / 93.3$ & \\
\hline No & 30 & 63.8 & 4 & 13.3 & 26 & 86.7 & $109.9 \pm 8.2$ & $86.7 / 70.6$ & \\
\hline Comorbidity & & & & & & & & & 0.062 \\
\hline Yes & 17 & 36.2 & 4 & 23.5 & 13 & 76.5 & $95.7 \pm 12.0$ & $77.8 / 48.6$ & \\
\hline No & 30 & 63.8 & 1 & 3.3 & 29 & 96.7 & $124.4 \pm 8.7$ & $96.0 / 96.0$ & \\
\hline Localization & & & & & & & & & 0.717 \\
\hline Central & 37 & 78.7 & 4 & 10.8 & 33 & 89.2 & $125.5 \pm 92$ & $91.5 / 76.0$ & \\
\hline Peripheral & 10 & 21.3 & 1 & 10 & 9 & 90.0 & $96.7 \pm 16.6$ & $66.7 / 66.7$ & \\
\hline T status & & & & & & & & & 0.300 \\
\hline $\mathrm{T}_{1}$ & 27 & 57.5 & 1 & 3.7 & 26 & 96.3 & $136.0 \pm 9.4$ & $88.9 / 88.9$ & \\
\hline $\mathrm{T}_{2}+\mathrm{T}_{3}$ & 20 & 42.5 & 4 & 20.0 & 16 & 80.0 & $105.5 \pm 9.9$ & $87.1 / 66.3$ & \\
\hline Histological type & & & & & & & & & 0.005 \\
\hline Typical & 40 & 85.1 & 2 & 5.0 & 38 & 95.0 & $120.2 \pm 5.8$ & $94.4 / 87.2$ & \\
\hline Atypical & 7 & 14.9 & 3 & 42.9 & 4 & 57.1 & $80.1 \pm 21.9$ & $55.6 / 27.8$ & \\
\hline $\mathrm{N}$ status & & & & & & & & & 0.008 \\
\hline No & 41 & 87.2 & 4 & 9.8 & 37 & 90.2 & $127.1 \pm 8.4$ & $90.5 / 76.8$ & \\
\hline $\mathrm{N}+$ & 6 & 12.8 & 1 & 16.7 & 5 & 83.3 & $33.0 \pm 3.6$ & $80.0 / 80.0$ & \\
\hline Pathological stage & & & & & & & & & 0.170 \\
\hline I & 39 & 83.0 & 3 & 7.7 & 36 & 92.3 & $128.8 \pm 9.1$ & $88.9 / 79.0$ & \\
\hline II+III & 8 & 17.0 & 2 & 25.0 & 6 & 75.0 & $95.0 \pm 18.5$ & $85.7 / 57.1$ & \\
\hline
\end{tabular}

SE: Standard error. 


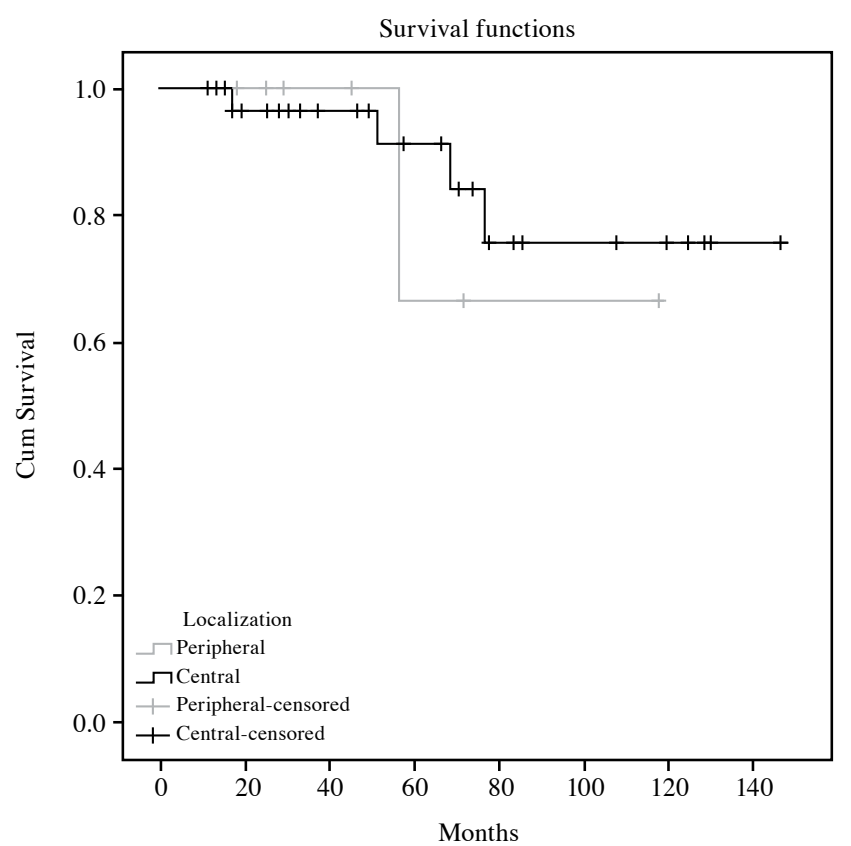

Figure 3. Prognostic influence of tumor location. Univariable analysis (Kaplan-Meier) $(\mathrm{p}=0.717)$.

$(\mathrm{n}=26 ; \mathrm{p}=0.433)$. In patients under and over 50 years of age, five-year survival was $100 \%$ and $81.2 \%$, respectively $(\mathrm{p}=0.474)$. In terms of smoking history, overall five-year survival was $93.3 \%$ in smokers and $86.7 \%$ in non-smokers $(\mathrm{p}=0.726)$.

\section{DISCUSSION}

Because carcinoid tumors are known to be benign for many years, most authors did not perform a systematic lymphadenectomy and the prognostic role of lymph nodal involvement could not be clarified. ${ }^{[3]}$ Universally accepted guidelines and randomized clinical trials still do not exist. Many reports agree that atypical histology is an important prognostic factor related to survival. However, other prognostic factors are not well defined. The aim of this study was to evaluate the prognostic factors affecting survival. We evaluated gender $(\mathrm{p}=0.433)$, age (under and over 50 years; $\mathrm{p}=0.474)$, smoking habits $(\mathrm{p}=0.726)$, comorbidity $(\mathrm{p}=0.062)$, tumor location (central versus peripheral; $\mathrm{p}=0.717)$, and $\mathrm{T}$ status $\left(\mathrm{T}_{1}\right.$ versus $\left.\mathrm{T}_{2}+\mathrm{T}_{3} ; \mathrm{p}=0.300\right)$, and we did not find any statistical correlation to survival. Only atypical histology $(\mathrm{p}=0.005)$ and nodal invasion $(p=0.008)$ were significantly correlated with survival. Filosso et al..$^{[3]}$ demonstrated that both atypical histology and lymphatic involvement were independent negative prognostic factors. Aydin et al. ${ }^{[4]}$ also emphasized the histological type and lymph-node involvement to be

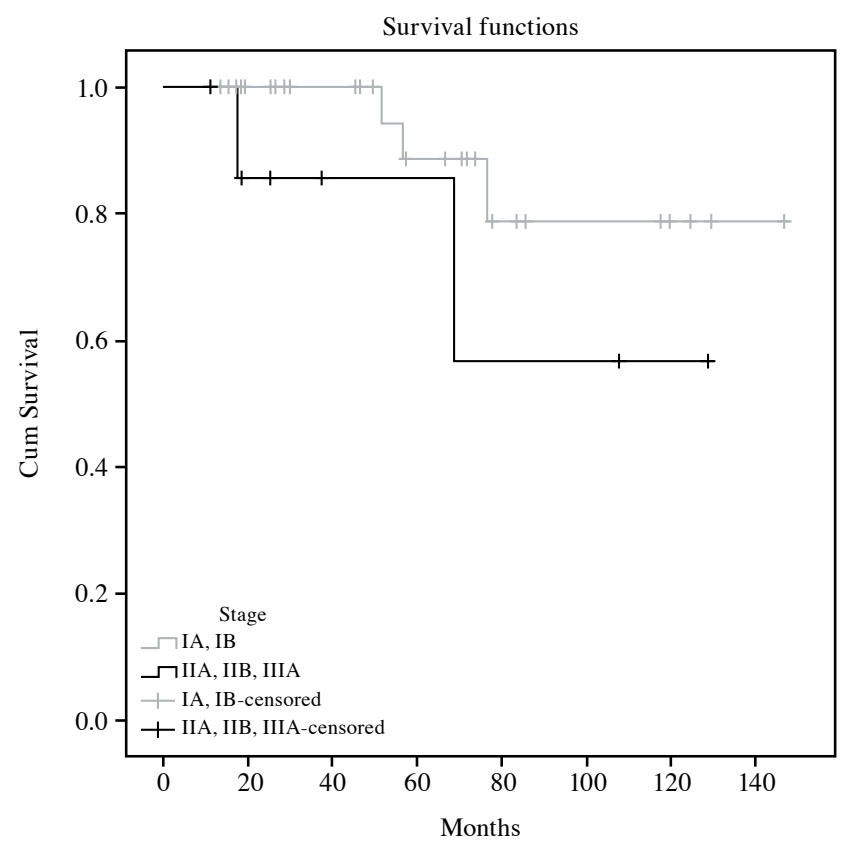

Figure 4. Cumulative survival of stage I (IA+IB) versus stage II (IIA+IIB) + IIIA. Univariable analysis (Kaplan-Meier) $(\mathrm{p}=0.170)$.

the most important prognostic factors effecting longterm survival. Nevertheless, Karapınar et al ${ }^{[5]}$ reported that, contrary to what was expected, $\mathrm{N}$ status did not have an effect on survival in their study.

Some studies emphasize a relationship between tobacco use and atypical carcinoids, but whether or not carcinoid tumors are associated with smoking is still a matter of debate. ${ }^{[6]}$ Thirty three percent of patients in our study with typical and $57 \%$ with atypical tumors were smokers, and we did not observe a statistically significant difference in terms of survival $(\mathrm{p}=0.726)$.

At present, some authors believe that intraoperative lymph node dissection may not be essential, especially in the surgical treatment of typical carcinoid tumors. ${ }^{[7]}$ Wurtz et al ${ }^{[8]}$ reported that systematic nodal dissection showed a high frequency of unpredictable lymphatic spread, mainly in the typical carcinoid group. A growing number of reports are emphasizing the potentially curative effect of systematic nodal dissection even in typical carcinoid tumors. ${ }^{[8-10]} \mathrm{We}$ also believe that surgical resection of carcinoid tumors and complete systematic lymph node dissection is necessary to determine possible lymph node metastasis. In our study, all patients underwent systematic mediastinal lymph node dissection. At least three lymph nodes from the $4^{\text {th }}, 7^{\text {th }}, 8^{\text {th }}, 9^{\text {th }}$, and $10^{\text {th }}$ zones in the right hemithorax and the $5^{\text {th }}, 6^{\text {th }}, 7^{\text {th }}, 8^{\text {th }}, 9^{\text {th }}$, and $10^{\text {th }}$ zones in the left hemithorax were dissected. Therefore, nodal 
status is an important prognostic factor in predicting survival and systematic nodal dissection is mandatory to treat carcinoids with curative intent.

Concerning the type of resection, some authors believe wedge resection to be safe for small peripheral typical carcinoid tumors. ${ }^{[7]}$ Fox et al. ${ }^{[1]}$ stated that, compared to lobectomy, sublobar resection is not inferior in regarding survival in typical carcinoid patients. But there are reports that sublobar resections may be related with locoregional recurrence, and high probability of missing eventual $\mathrm{N}_{1}$ lymph nodes. ${ }^{[3,9]}$ Aydin et al. ${ }^{[4]}$ reported that overall survival was lowest in the wedge group. Therefore, we also recommend completion lobectomy when frozen section is tumor free but paraffin positive, in case of wedge resection cases. Carcinoid tumors are malignant neoplasms and should be treated with anatomical resection. Nonanatomic resection was not performed in our study. The latest publications also noted that parenchyma-sparing resections are suitable for proximal carcinoid tumors. ${ }^{[12]}$

In conclusion, we demonstrated that atypical presentation $(\mathrm{p}=0.005)$, and nodal invasion $(\mathrm{p}=0.008)$ were both negative prognostic factors. Prognosis does not seem to be related to sex $(\mathrm{p}=0.433)$, age $(\mathrm{p}=0.474)$, smoking history $(\mathrm{p}=0.726)$, comorbidity $(\mathrm{p}=0.062)$, central or peripheral localization $(\mathrm{p}=0.717)$, or $\mathrm{T}$ status $(\mathrm{p}=0.300)$. For optimal oncological results, an anatomic lung resection associated with systematic mediastinal lymphadenectomy is crucial.

\section{Declaration of conflicting interests}

The authors declared no conflicts of interest with respect to the authorship and/or publication of this article.

\section{Funding}

The authors received no financial support for the research and/or authorship of this article.

\section{REFERENCES}

1. Naalsund A, Rostad H, Strøm EH, Lund MB, Strand TE. Carcinoid lung tumors--incidence, treatment and outcomes: a population-based study. Eur J Cardiothorac
Surg 2011;39:565-9.

2. Travis WD, Brambilla E, Muller-Hermlink HK, Harris CC. World Health Organization classification of tumors. Pathology and genetics of tumours of the lung, pleura, thymus and heart. Lyon: IARC Press; 2004.

3. Filosso PL, Oliaro A, Ruffini E, Bora G, Lyberis P, Asioli $\mathrm{S}$, et al. Outcome and prognostic factors in bronchial carcinoids: a single-center experience. J Thorac Oncol 2013;8:1282-8.

4. Aydin E, Yazici U, Gulgosteren M, Agackiran Y, Kaya S, Gulhan E, et al. Long-term outcomes and prognostic factors of patients with surgically treated pulmonary carcinoid: our institutional experience with 104 patients. Eur J Cardiothorac Surg 2011;39:549-54.

5. Karapınar K, Saydam Ö, Büyükkale S, Metin M, Günlüoğlu Z, Demir A, et al. Long-term results of surgical treatment of pulmonary carcinoids. Turk Gogus Kalp Dama 2015;23:304-8.

6. Filosso PL, Rena O, Donati G, Casadio C, Ruffini E, Papalia E, et al. Bronchial carcinoid tumors: surgical management and long-term outcome. J Thorac Cardiovasc Surg 2002;123:303-9.

7. Ferguson MK, Landreneau RJ, Hazelrigg SR, Altorki NK, Naunheim KS, Zwischenberger JB, et al. Long-term outcome after resection for bronchial carcinoid tumors. Eur J Cardiothorac Surg 2000;18:156-61.

8. Wurtz A, Benhamed L, Conti M, Bouchindhomme B, Porte H. Results of systematic nodal dissection in typical and atypical carcinoid tumors of the lung. J Thorac Oncol 2009;4:388-94.

9. Cañizares MA, Matilla JM, Cueto A, Algar J, Muguruza I, Moreno-Mata N, et al. Atypical carcinoid tumours of the lung: prognostic factors and patterns of recurrence. Thorax 2014;69:648-53.

10. García-Yuste M, Matilla JM, Cueto A, Paniagua JM, Ramos G, Cañizares MA, et al. Typical and atypical carcinoid tumours: analysis of the experience of the Spanish Multicentric Study of Neuroendocrine Tumours of the Lung. Eur J Cardiothorac Surg 2007;31:192-7.

11. Fox M, Van Berkel V, Bousamra M 2nd, Sloan S, Martin RC 2nd. Surgical management of pulmonary carcinoid tumors: sublobar resection versus lobectomy. Am J Surg 2013;205:200-8.

12. Dadaş E, Tanju S, Özkan B, Bayrak Y, Kaba E, Dilege Ş, et al. Surgical management of bronchial carcinoid tumors: 11-year experience. Turk Gogus Kalp Dama 2014;22:795-9. 